\title{
Saddle pulmonary embolism as the initial presentation of prothrombin gene mutation G20210A
}

\author{
Amirali Kiyani, ${ }^{1}$ Shannon Ursu ${ }^{2}$
}

${ }^{1}$ Department of Internal Medicine, Maricopa Medical Center, Phoenix, Arizona, USA ${ }^{2}$ Maricopa Medical Center, Phoenix, Arizona, USA

\section{Correspondence to} Dr Amirali Kiyani, amirali. kiyani@mihs.org

Accepted 21 November 2016
CrossMark

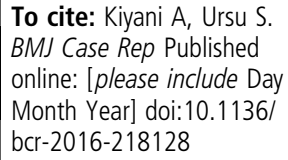

\section{DESCRIPTION}

A Hispanic man aged 28 years with intermittent tobacco and cocaine use presented to the emergency department with acute shortness of breath for 2 days duration in addition to brief calf pain a few days prior that had resolved. He had sustained tachycardia 120-130 bpm but otherwise unremarkable examination, chest X-ray (figure 1) and EKG. D-dimer was elevated at $2586 \mathrm{ng} / \mathrm{mL}$. CT angiogram revealed extensive thrombus burden, including saddle emboli (figure 2), and segmental and subsegmental emboli (figure 3). Echocardiogram showed severely enlarged right ventricle (figure 4) with markedly elevated right systolic ventricular pressure of $54 \mathrm{~mm} \mathrm{Hg}$ (figure 5). Owing to concern of impending cardiovascular collapse, catheter-guided thrombolysis of pulmonary embolism (PE) was carried out. During the angiogram, a near occlusive right popliteal vein thrombus with extension to femoral vein was identified and treated with thrombectomy followed by inferior

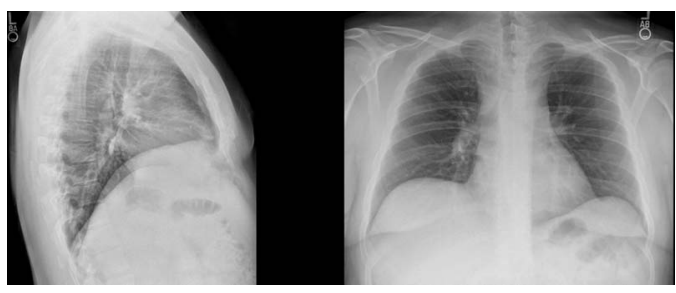

Figure 1 Chest X-ray shows normal lung parenchyma with mild bronchial wall thickening.

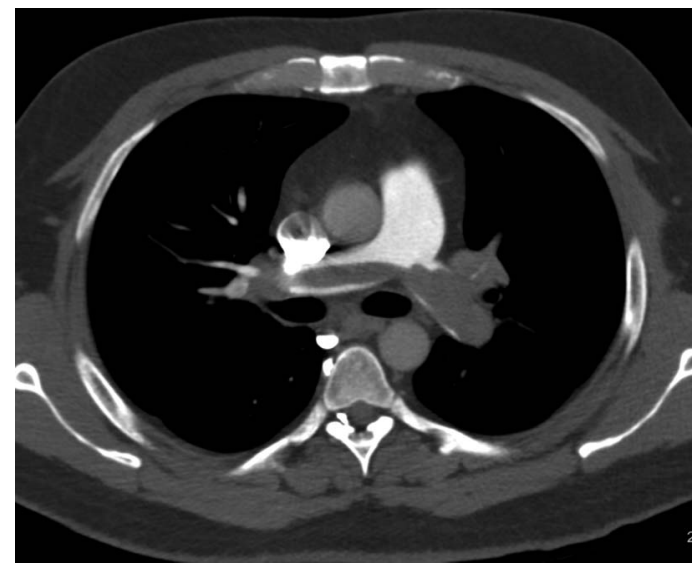

Figure 2 Chest CT angiogram shows thrombus within the main pulmonary artery extending into the left main and right main pulmonary arteries (saddle embolus).

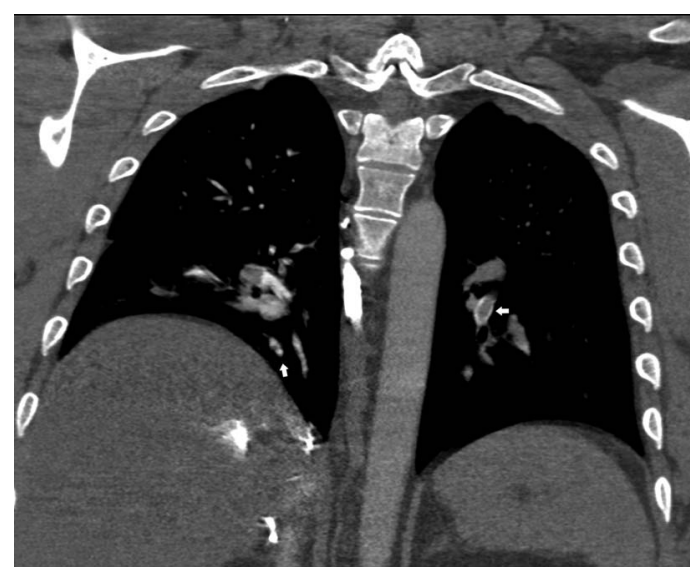

Figure 3 Chest CT angiogram shows subsegmental (arrows) thrombus in both lungs.

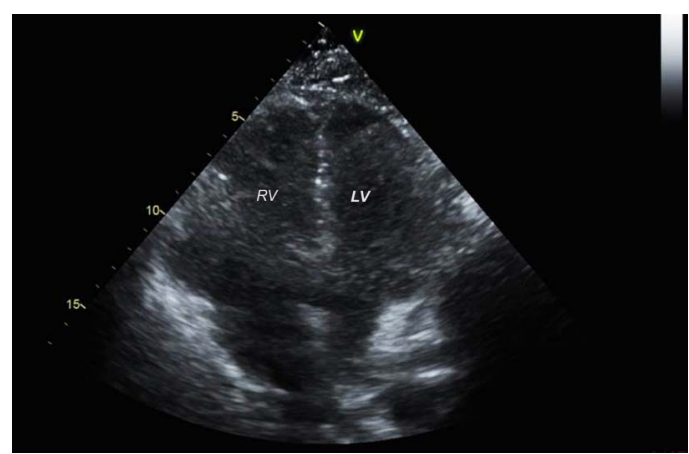

Figure 4 Echocardiogram (apical four-chamber view) shows severe right ventricle enlargement.

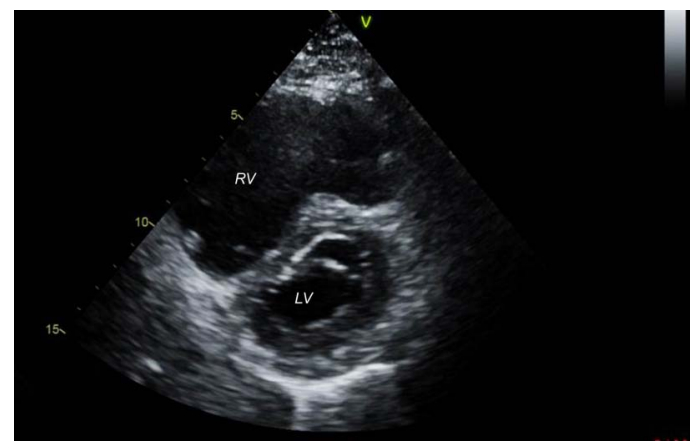

Figure 5 Echocardiogram (short-axis view) shows 'D-shaped' intraventricular septum with estimated right systolic ventricular pressure of $54 \mathrm{~mm} \mathrm{Hg}$. 


\section{Learning points}

- Hereditary thrombophilia are rare genetic mutations that can present with venous thromboembolisms (VTEs) at young age without any other identifiable risk factors.

- Not every patient with first episode of unprovoked VTE requires thrombophilia screening. When screening is warranted, except for gene mutation studies (prothrombin gene mutation and factor $\mathrm{V}$ Leiden), further investigation for hereditary thrombophilia (protein $S$ deficiency, antithrombin III deficiency, etc) should not be performed during the acute episode or while the patient is on anticoagulation, to avoid erroneous results.

- Based on the presentation, treatment options are oral and parenteral anticoagulation with or without medical or surgical thrombolytic therapy.

vena cava filter placement. He was discharged on lifelong anticoagulation. Further investigation showed he was heterozygous for prothrombin gene mutation (G20210A).

Factor V Leiden mutation and the prothrombin gene mutation (G20210A mutation) are the most common types of hereditary thrombophilia with marked risk of venous thromboembolism (VTE) incidence. Not every patient with first time VTE needs to be screened for hereditary thrombophilia, especially those with active cancer, transient risk factors or superficial VTE. Adult patients with the following conditions merit screening for hereditary thrombophilia: unprovoked or idiopathic VTE at a young age (age <40), recurrent idiopathic
VTE, warfarin-induced skin necrosis, strong family history of VTE (defined as two or more first-degree relatives or $>20 \%$ symptomatic relatives) or unexplained spontaneous abortions. ${ }^{12}$ Thrombophilia screening in cases of VTE at unusual sites (eg, intra-abdominal, cerebral vein thrombosis) and arterial thrombosis are still controversial. Noteworthy, genetic testing will not impact the treatment of the affected patient, but it may impact the duration of therapy and screening additional family members, particularly in primary relatives, especially women in childbearing ages.

Treatment generally includes oral and parenteral anticoagulation. Patients with intermediate to high-risk PE with haemodynamic decompensation may be considered for thrombolytic therapy, alternative surgical pulmonary embolectomy or percutaneous catheter-directed treatment. ${ }^{3}$ Most experts recommend extended therapy (lifelong) after the first presentation of unprovoked VTE in patients with low to moderate risk of bleeding.

Contributors AK has written the main portion of the case report and SU as the supervising author has performed the final editing.

Competing interests None declared.

Patient consent Obtained.

Provenance and peer review Not commissioned; externally peer reviewed.

\section{REFERENCES}

1 Baglin T, Gray E, Greaves M, et al. Clinical guidelines for testing for heritable thrombophilia. Br J Haematol 2010;149:209-20.

2 Shen YM, Tsai J, Taiwo E, et al. Analysis of thrombophilia test ordering practices at an academic center: a proposal for appropriate testing to reduce harm and cost. PLOS ONE 2016:11:e0155326.

3 Konstantinides S, Torbicki A, Agnelli G, et al. 2014 ESC guidelines on the diagnosis and management of acute pulmonary embolism. Eur Heart J 2014;35:3033-69.

Copyright 2016 BMJ Publishing Group. All rights reserved. For permission to reuse any of this content visit

http://group.bmj.com/group/rights-licensing/permissions.

BMJ Case Report Fellows may re-use this article for personal use and teaching without any further permission.

Become a Fellow of BMJ Case Reports today and you can:

- Submit as many cases as you like

- Enjoy fast sympathetic peer review and rapid publication of accepted articles

- Access all the published articles

- Re-use any of the published material for personal use and teaching without further permission

For information on Institutional Fellowships contact consortiasales@bmjgroup.com

Visit casereports.bmj.com for more articles like this and to become a Fellow 